\title{
Computer Education in Spain: From Early to Recent Times
}

\section{Ramon Puigjaner}

Univeristat de les Illes Balears, Ctra de Valldemossa, km 7.5, 07122 Palma (Spain) putxi@uib.cat

\begin{abstract}
This paper intends to present a short overview of the evolution of computer education in Spain since the initial teaching in this domain to the current works to adapt it to the European Higher Education Space (EHES) from the point of view of somebody that has been involved has directly participated in most of the this evolution.
\end{abstract}

Keywords: Computer science education history, Computer science curricula, Computer science in Spain

\section{Remote Precursors}

Here is not the proper place to talk about the precursors of computing machines. However, at least it is convenient to mention Ramon Llull (Raimundus Lullius) who in the XIII century invented several logical machines oriented to convert the Muslims to the, for him, truth religion, and Leonardo Torres Quevedo and Esteve Terrades who in late XIX and early XX centuries built several analogical machines to solve complicated analytical calculations.

\section{Early University Courses: Decade of 1960}

At university level just the Universidad Complutense de Madrid had an Automatic Computation specialty with some courses on the basic computer architecture and on programming, common to the curricula on Mathematics and Physics, and the Industrial Engineering Schools had a course on Computers in which was mainly explained the basic von Neumann architecture and the FORTRAN language.

In March 1969, the Ministry of Education created the Instituto de Informatica, [5] a strange organization, without any contact with the university and giving a 
strange curriculum: the students earned a different title after each one of the five years of studies. With these degrees, it was intended that people who earned them were ready to develop professional tasks in industry and companies. It is easy to understand the difficulties of simultaneously giving a solid background and the practical knowledge associated to each degree.

In October 1967, the Asociación de Técnicos de Informática was created in Barcelona that developed an important educational task (mainly courses on data structures, basic computer organization, programming languages, operating systems, etc.) oriented to give a computer science background to the people working with computers at that time without any formal education in computer science.

\section{Computer Science Arrives to the University: Decade of 1970}

The Instituto de Informática started its regular courses in 1970 according to the above commented curriculum. It created a delegation in Donostia in 1971 and in 1972, the Universitat Autònoma de Barcelona created a Department of Informatics in its Faculty of Sciences. This Faculty was obliged to follow the same curriculum of the Instituto de Informática. The team that started to teach computer Science in this University was a mixture of good professionals and people having followed some university computer courses, mainly in France (Paris and Grenoble); they kept the titles of the official curriculum but they tried to transform the contents into a more reasonable structure according the university spirit.

In 1974, the Spanish Ministry of Education considered that Informatics should be included in the regular university structure. A commission was created to study how to pass the Instituto de Informática and its satellites to the university. Several universities fight in this commission to get the computer studies. Finally by the end of 1975 was decided that three Faculties of Informatics had to be created: Barcelona (in the Universitat Politècnica de Catalunya), Donostia (in the Euskal Herriko Unibertsitatea) and Madrid (in the Universidad Politécnica de Madrid), and that the previous institutions giving informatics studies had to stop to teach informatics [6]. This was true in Madrid and Donostia because the Instituto de Informática and its delegation were incorporated at the corresponding universities and their denomination changed. In Barcelona, the situation was more complicated because it was necessary to passing studies from one university to another (unbelievable in Spain at that time). Finally, both universities kept their studies. The new Faculties started to work in October 1977 with a five-year curriculum that, for the first time in Spain, was different for each university. In addition, in the Faculty of Barcelona the classical curriculum structure of a set of courses per academic year was broken. The curriculum was organized by courses with their 
corresponding pre-requisites in such a way that the student was able to organize his/her own curriculum choosing courses among those offered by the Faculty but respecting some compulsory courses [7]. In all cases, curricula were planned for five years of studies. Curricula of the Madrid and Donostia Faculties followed the traditional structure. In all cases, but especially in the Faculty of Barcelona, curricula were inspired by the ACM Computer Curriculum 1968 [1]. The students that successfully followed the studies in one of these universities obtained the title of Licenciado en Informática (Licensed in Informatics).

For its novelty at that moment, the structure of the Faculty of Barcelona and its curriculum follows: The Faculty was organized around eight departments: Mathematics, Theoretical Computer Science, Computer Programming, Computer Architecture, Physical Systems, Automatic and Hybrid Systems, Statistics, and Information Systems. Students arriving to the Faculty had a first year with the following courses:

- Computers and programming

- Algebra

- Mathematical Analysis I (Infinitesimal calculus)

- Representation techniques

- Physics

To get the first cycle of this License it was compulsory to succeed in the following courses:

- Mathematical analysis II

- Computer structure

- Information structure

- Programming technology

- Statistics

- Operating systems

Each course has assigned a number of credits (1 credit was 1 hour of course during an academic year) and to earn the first cycle a student should get courses for an amount of 75 credits and to earn the second cycle (Licenciado en informática) a student should get courses for an amount of 50 supplementary credits.

Each course had some pre-requisites, could be compulsory (C) or optional (O) and be valid for just the first cycle (F) or for both (B). A (C) besides some prerequisite means that both courses can be followed in parallel. Appendix A shows tables that describe courses for different departments.

\section{General Restructuring of University Studies: Decade of 1980}

Around 1980 a new three years study in Informatics was created and started in Madrid (Universidad Politécnica de Madrid) and Valencia (Universitat 
Politècnica de València). The students that successfully followed these stdies obtained the title of Diplomado en Informática (Diplomat in Informatics). Few after the Universidad de Las Palma de Gran Canaria and the Univeristat de les Illes Balears (Palma de Mallorca) created three years studies in Informatics. When these studies in Valencia, Las Palmas, and Palma arrived to the third year, extensions to five years were implemented in Valencia, Las Palmas and Palma de Mallorca. These three years studies had two orientations or intensifications:

- Computer systems, mainly devoted to a vision of the computer under the user interface

- Business management applications

In the last years of this decade the Spanish Ministry of Education started a general reorganization of all university studies creating a catalogue of official titles (those delivered by the Ministry itself based on the studies done in some university)reorganizing the existing titles and creating new ones. To get the official acceptance by the Ministry each one of these titles should respect a set of contents established by the Ministry (main topics). To describe the relative importance of each of these topics a measure was invented: the credit equivalent to a ten hours of teaching (including all kind of activities driven by the university teaching staff: theoretical classes, practical classes, etc.) received by the students. An academic year was estimated to have thirty weeks.

In the case of informatics, three new titles were created and disappeared those existing until that moment:

- Ingeniero en Informática (Informatics Engineer): five years divided in two cycles and between 300 and 400 credits [8].

- Ingeniero Técnico en Informática de Sistemas (Technical Engineer in Informatics: Computer systems orientation): three years and between 180 and 225 credits [9].

- Ingeniero Técnico en Informática de Gestión (Technical Engineer in Informatics: Computer business management orientation): three years and between 180 and 225 credits [10].

The main contents of these new careers appear in Appendix B. In addition, it was stated that the students having earned one of the two three-year degrees were allowed to follow the second cycle of Ingeniero en Informática.

\section{Setup of the New Careers: Decade of 1990}

In the early years of this decade, all universities giving the old degrees in informatics adapted their curriculum to the new characteristics. This adaptation took different solutions:

- Universities that delivered the three degrees separately: the five-year degree in a faculty or school and the three-year degree in a different school. 
- Universities that delivered the three degrees in the same faculty or school with a complete implementation of the three degrees.

- Universities that delivered the three degrees in the same faculty or school but without the implementation of the first cycle of Ingeniero en Informática and using both three-year degrees as the first cycle.

- Universities that had just the five-year degree.

- Universities that had both three-year degrees.

However, soon several problems appeared:

- The fact that three different first cycles gave access to the second cycle introduced difficulties in different topics like networks, computer architecture and software engineering. The reasons were that sometimes the same main topic with the same descriptors had assigned different number of credits or that the student coming from some first cycle had a previous knowledge of some topic unknown for the students coming from other first cycles.

- The low number of credits assigned to operating systems that obliged to most of universities to create supplementary courses in this topic.

- The growing importance of networking and it was possible that an Ingeniero Técnico en Informática de Gestion could earn his/her title with no knowledge on this topic.

- The inconvenience of having automata theory as a compulsory topic in the first cycle of Ingeniero en Informática (too theoretical for beginners) and in Ingeniero Técnico en Informática de Sistemas (too theoretical for the applied orientation of the three years studies).

During this period, the number of faculties and schools delivering these degrees was continuously increasing (and currently there are approximately 80 in Spain). This fact and the need of exchanging information about experiences and discussing about the difficulties in the implementation of their curricula provoked the need of discussion meetings with the participation of all faculties and schools teaching informatics careers. These annual meetings started in 1995. However, as the number of schools and faculties was continuously increasing, in 1998 it was decided to set up a minimal organization: a president and a secretary, and a title: Conferencia de Decanos y Directores de Centros Universitarios de Informática, CODDI (Conference of Deans and Directors of Inforamtics University Centres). The first task assigned just after this designation was the review of the main topics of the informatics careers in order to correct the detected inconveniences. In 1999 this task was completed and the result was [4]. Appendix $C$ shows the results.

This new definition of the main topic for the three degrees corrected the main defaults of the previous one:

- The same topic had the same description and the same number of credits.

- Networking was compulsory in the three first cycles.

- Too theoretical topics disappeared from the first cycles.

- Mathematics was split between Algebra and Analysis. 
- Operating systems had a greater number of compulsory credits.

CODDI submitted this proposal to the Ministry of Education. However, it was not accepted because its acceptation would have allowed other careers to request also the modification of their compulsory main topics. Moreover, this would have introduced a high degree of discussions between universities and between these and the Ministry. Nevertheless, it was accepted as guidelines for the analysis and acceptation of future curricula submitted to the Ministry by the universities.

\section{Towards the European Higher Education Space (EHES): Current Decade}

In coincidence with the change of millennium, the European Union decided ask the member states to reorganize their university systems in such a way that a convergence was reached around 2010 in two main points:

- University studies should be organized in three levels: bachelor, master, and doctorate.

- University studies should define for each course the effort required to the student, the ECTS credit, equivalent, approximately to 25 to 30 hours of work for the student including all his/her activities (theoretical courses, practical courses, seminars, personal study, etc.).

This convergence was named as the Bologna process because the agreement of all the member states was reached in a meeting held city where the first European university was created.

In 2001, CODDI started to work on how to adapt the informatics studies to this convergence process. Initially a set of considerations showing mismatches either in the university studies structure or in the consideration by the society of the degrees delivered by the university [2]. These considerations were:

- It was observed that neither the market nor the universities have succeeded to clearly discern the professional and educational differences between the Ingenierías Técnicas en Informática and the Ingeniería en Informática due to the constant evolution of the informatics and the professional changes.

- The difficulties found at the second cycle of the Ingeniería en Informática due to coexistence of students coming from three different first cycles.

- The fact that the Ingenieros Técnicos have not a professional acknowledgement at European level as university graduates.

- The difficulty for defining competencies and responsibilities of the informatics professionals

- The great number of new activities with a fuzzy limit with other engineering branches (telecommunication engineers, industrial engineers, etc.). 
- The consequences of the effort done to offer a higher non university education, public as well as private, oblige to reconsider the structure, contents and level of the informatics university studies

The main conclusions of these discussions were [3]:

- An initial premise says that the market will experience a strong growing of the demand in a near future. The strategic presence of the informatics suggests the need of a set of solutions considering all education levels (primary education, secondary education, vocational education) and not only the university one.

- In this sense a deep consideration about the University programming should be done to take into account the geographical distribution and the resources needed to attain the planned objectives.

- The university structure will be organized in two cycles: Grado (degree) and Master.

- There should be just a unique title of Grado whose name will be Ingeniería en Informática (informatics engineering).

- The title of Ingeniero en Informática will furnish full professional competencies for the exercise of the profession.

- The education furnished at the Grado level will general in the informatics domain.

- The Grado studies will have 240 ECTS credits organized en 4 years.

- Among the fundamental educational contents of the Grado, there should be an End of Studies Project, that will integrate the knowledge acquired by the student during his/her studies and that will make an approximation to real professional cases as well as to transversal contents that put in evidence his/her abilities for the exercise of engineering activities.

- The common educational contents of the Grado should represent about $60 \%$ of the total study load, including the End of Studies Project, leaving a $40 \%$ for topics to be freely decided by each university.

- Among the courses to be freely decided by the universities, it is recommended to have an enough large offer of courses oriented to give the students a solid knowledge of the current informatics technologies as well as its application domains.

- The Master will have as objective the professional specialization of the Ingeniero en Informática or his/her preparation for the research.

- The number of Master degrees should be large enough to cover the demand of specialized professionals at every moment.

- Master studies will have between 60 and 120 ECTS credits, depending on the previous degree earned and will include some effort allocated to a Master Thesis

- The Master degree will allow the access to the preparation of a doctoral thesis to obtain the Doctor degree.

The structure of the studies appears in Table 1. 
Table 1 Current Structure of Studies

\begin{tabular}{|c|c|c|c|c|c|}
\hline Contents & & & Min. & Max & \\
\hline & & Scientific base & $10 \%$ & $15 \%$ & $\begin{array}{l}\text { Informatics } \\
\text { mathematical } \\
\text { fundamentals } \\
\text { Informatics physical } \\
\text { fundamentals }\end{array}$ \\
\hline \multirow[t]{3}{*}{$\begin{array}{l}\text { Common } \\
\text { educational } \\
\text { contents }\end{array}$} & \multirow[t]{3}{*}{$60 \%$} & $\begin{array}{l}\text { Informatics } \\
\text { engineering specific } \\
\text { contents }\end{array}$ & $35 \%$ & $40 \%$ & $\begin{array}{l}\text { Programming } \\
\text { Software engineering } \\
\text { Information systems } \\
\text { engineering } \\
\text { Intelligent systems } \\
\text { engineering } \\
\text { Operating systems } \\
\text { Distributed systems } \\
\text { and networking } \\
\text { Computer engineering }\end{array}$ \\
\hline & & $\begin{array}{l}\text { General contents of } \\
\text { engineering }\end{array}$ & $5 \%$ & $10 \%$ & $\begin{array}{l}\text { Business management } \\
\text { Ethical, legal and } \\
\text { professional aspects } \\
\text { Professional abilities }\end{array}$ \\
\hline & & End of studies project & $6 \%$ & $6 \%$ & \\
\hline $\begin{array}{l}\text { Contents freely } \\
\text { decided by the } \\
\text { university }\end{array}$ & $40 \%$ & & & & \\
\hline Total effort & & 240 ECTS credits & & & \\
\hline
\end{tabular}

The students that earn the Grado en Ingeniería en Informática should be characterized by:

- To be prepared to exercise his/her profession, having a clear knowledge of the human, economic, social, legal, and ethical dimension.

- To be prepared to assume responsibility tasks in any kind of organization along his/her professional life, in technical and in managerial positions, and to contribute in the information and knowledge management.

- To have the required abilities in the professional practice of the engineering: to be able to manage projects, to communicate in a clear and effective way, to work in a multidisciplinary team as well as to manage it, to adapt himself/herself to the changes and to autonomously learn along with his/her life.

- To be prepared to learn and to use in an effective way techniques and tools that could appear in the future. This versatility is especially valuable in organizations in which a permanent innovation is needed. 
- To be able to specify, design, build, verify, audit, evaluate, and maintain informatics systems giving answers to the user needs.

- To have the basic education to be able to continue his/her studies of Master and Doctorate in Spain or elsewhere.

\section{The Future: Decade of 2010}

Currently the Ministry of Education is setting up the framework for the implementation of the EHES [11]. Some points are clear but the framework is not yet complete:

- There will not be a catalogue of official titles. Each university must propose its own titles that will be validated by an independent agency (Agencia Nacional de Evaluación de la Calidad del Sistema Universitario, ANECA, National Agency for the Evaluation of the Quality of the University System) that will evaluate the appropriateness of the proposed title (specially avoiding confusion to the society), the quality of the proposal and the sufficient amount of the human and material resources allocated.

- The grade, in our case of Ingeniero en Informática, will have 240 ECTS credits that will include the end of studies project.

- The master degree will have 60 or 120 ECTS credits depending on the coherence between the grade earned and the intended Master.

From this information, it is easy to see that the proposal of the CODDI, several years before the decisions of the Ministry, is fully in line with the framework in which the universities will work in a near future.

Currently the universities are preparing the curricula for all the studies they are planning to offer to the students and soon the ANECA will start its evaluation tasks.

What will the future be?

\section{References}

1. ACM Curriculum Committee on Computer Science, "Curriculum '68 - Recommendations for Academic Programs in Computer Science,” Comm. ACM, vol. 11, no. 3, pp. 151-197, Mar. 1968.

2. J. Campos, J. Casanovas, J. M. Colom, G. Martín, J Martínez, A. Pont, R. Puigjaner, A. Robles, M. R. Sancho: Informe sobre la adaptación de los estudios de TIC a la declaración de Bolonia. Unpublished document. 2002 (For getting it, contact the author of this article).

3. J. Casanovas et al.: Libro Blanco sobre las titulaciones universitarias de informática en el nuevo espacio europeo de educación superior. ANECA 2004.

4. Conferencia de Decanos y Directores de Centros Universitarios de Informática (CODDI): Nuevas directrices generales propias de los títulos de Ingeniero en Informática, de 
Ingeniero Técnico en Informática de Sistemas y de Ingeniero Técnico en Informática de Gestión. Unpublished document. 1999 (for getting it, contact the author of this article).

5. Ministerio de Educación y Ciencia (BOE de 14/04/1969 - Sección I): Decreto 554/1969, de 29 de marzo (Educación y Ciencia), por el que se crea un Instituto de Informática, dependiente del Ministerio de Educación y Ciencia, con sede en Madrid, y se regulan las enseñanzas del mismo.

6. Ministerio de Educación y Ciencia (BOE de 26/03/1976 - Sección I): Decreto 593/1976, de 4 de marzo, por el que se crean Facultades de Informática en Barcelona, Madrid y San Sebastián.

7. Ministerio de Educación y Ciencia (BOE de 27/07/1977 - Sección I): Orden de 7 de junio de 1977 por la que se aprueba el plan de estudios de la FAcultad de Informática de Barcelona.

8. Ministerio de Educación y Ciencia (BOE de 20/11/1990 - Sección I): Real decreto 1459/1990, de 26 de octubre, por el que se establece el título universitario oficial de Ingeniero en Informática y las directrices generales propias de los planes de estudios conducentes a la obtención de aquél.

9. Ministerio de Educación y Ciencia (BOE de 20/11/1990 - Sección I): Real decreto 1459/1990, de 26 de octubre, por el que se establece el título universitario oficial de Ingeniero Técnico en Informática de Sistemas y las directrices generales propias de los planes de estudios conducentes a la obtención de aquél.

10. Ministerio de Educación y Ciencia (BOE de 20/11/1990 - Sección I): Real decreto 1459/1990, de 26 de octubre, por el que se establece el título universitario oficial de Ingeniero Técnico en Informática de Gestión y las directrices generales propias de los planes de estudios conducentes a la obtención de aquél.

11. Ministerio de Educación y Ciencia (BOE de 30/10/2007 - Sección I): Real decreto 1393/2007, de 29 de octubre, por el que se establece la ordenación de las enseñanzas universitarias oficiales. 


\section{Appendix A}

\section{Department of Mathematics}

\begin{tabular}{|l|c|c|c|c|c|}
\hline \multicolumn{1}{|c|}{ Course } & Acronym & Credits & Pre-req. & Class & Validity \\
\hline Algebra & AL & 5 & None & C & F \\
\hline Mathematical analysis I & AM-1 & 5 & None & C & F \\
\hline Mathematical analysis II & AM-2 & 6 & AN-1 & C & F \\
\hline Numerical calculus & CN & 4 & AL, AN-2, TR & O & F \\
\hline Representation techniques & TR & 3 & None & C & F \\
\hline Numerical analysis & AN & 4 & CN & O & B \\
\hline Information and coding theory & TIC & 4 & AF, E & O & B \\
\hline
\end{tabular}

\section{Department of Theoretical Computer Science}

\begin{tabular}{|l|c|c|c|c|c|}
\hline \multicolumn{1}{|c|}{ Course } & Acronym & Credits & Pre-req. & Class & Validity \\
\hline Finite automata & AF & 6 & AL, E & O & B \\
\hline Computability theory & TC & 4 & AF & O & B \\
\hline Language theory & TL & 4 & C, AF & O & B \\
\hline Mathematical logic & LM & 4 & AL, CP & O & B \\
\hline Artificial intelligence & AI & 4 & LM, TL, AD & O & B \\
\hline
\end{tabular}

\section{Department of Computer Programming}

\begin{tabular}{|l|c|c|c|c|c|}
\hline \multicolumn{1}{|c|}{ Course } & Acronym & Credits & Pre-req. & Class & Validity \\
\hline Computers and programming & CP & 7 & None & C & F \\
\hline Information structure & EI & 4 & CP & C & B \\
\hline Programming languages & LP & 4 & AL, CP & O & B \\
\hline Programming technology & TP & 4 & AL, CP & C & B \\
\hline Compilers & C & 4 & EI, LP & O & B \\
\hline Files and data bases & FBD & 5 & EI, LP & O & B \\
\hline
\end{tabular}




\section{Department of Computer Architecture}

\begin{tabular}{|l|c|c|c|c|c|}
\hline \multicolumn{1}{|c|}{ Course } & Acronym & Credits & Pre-req. & Class & Validity \\
\hline Computer structure & EC & 4 & CP, AL & C & F \\
\hline Operating systems & SO & 4 & EC, EI, TP & C & B \\
\hline Computer architecture & AC & 4 & EC, AF & O & B \\
\hline $\begin{array}{l}\text { Design and evaluation of } \\
\text { configurations }\end{array}$ & DAC & 4 & AC, SI & O & B \\
\hline $\begin{array}{l}\text { Communications and computer } \\
\text { networks }\end{array}$ & CRC & 4 & SO, AC, SI & O & B \\
\hline Operating systems design & DSO & 4 & SO, AC & O & B \\
\hline Diagnostic and reliability & DF & 4 & AC, TIC & O & B \\
\hline
\end{tabular}

\section{Department of Physical Systems}

\begin{tabular}{|l|c|c|c|c|c|}
\hline \multicolumn{1}{|c|}{ Course } & Acronym & Credits & Pre-req. & Class & Validity \\
\hline Physics & F & 5 & None & C & F \\
\hline Electronics & EL & 4 & F, AN-1 & O & F \\
\hline Digital circuits & CD & 4 & EL, AF & O & B \\
\hline Design of computers & DC & 4 & CD, AC, DAH & O & B \\
\hline Peripheral equipments & EP & 4 & CD & O & B \\
\hline Analogical and hybrid design & DAH & 4 & EL & O & B \\
\hline
\end{tabular}

\section{Department of Automatic and Hybrid Systems}

\begin{tabular}{|l|c|c|c|c|c|}
\hline \multicolumn{1}{|c|}{ Course } & Acronym & Credits & Pre-req. & Class & Validity \\
\hline Systems and signals & SS & 4 & AN-2, ES (c) & O & B \\
\hline System dynamics & DS & 4 & SS & O & B \\
\hline Optimal control and filtering & COF & 4 & DS, PE & O & B \\
\hline Analogical and hybrid calculus & CAH & 4 & AN-2, LP, EL & O & B \\
\hline $\begin{array}{l}\text { Architecture and design of } \\
\text { control systems }\end{array}$ & ADSM & 4 & SS, CAH & O & B \\
\hline Real-time operating systems & SOTR & 4 & SO, SS & O & B \\
\hline
\end{tabular}




\section{Department of Statistics}

\begin{tabular}{|l|c|c|c|c|c|}
\hline \multicolumn{1}{|c|}{ Course } & Acronym & Credits & Pre-req. & Class & Validity \\
\hline Statistics & E & 5 & AL, AN-2 & C & F \\
\hline Simulation & SI & 4 & E & O & B \\
\hline Data analysis & AD & 3 & E & O & B \\
\hline Stochastic processes & PE & 4 & E & O & B \\
\hline Optimization & O & 5 & $\begin{array}{c}\text { AN-2, AL, E } \\
\text { (c) }\end{array}$ & O & B \\
\hline Optimization algorithms & AO & 4 & E, O & O & B \\
\hline Operational research & OR & 4 & E, O & O & B \\
\hline
\end{tabular}

\section{Department of Information Systems}

\begin{tabular}{|l|c|c|c|c|c|}
\hline \multicolumn{1}{|c|}{ Course } & Acronym & Credits & Pre-req. & Class & Validity \\
\hline Economy & ECO & 3 & None & O & F \\
\hline $\begin{array}{l}\text { Design and utilization of files } \\
\text { and data bases }\end{array}$ & DUABD & 3 & EI, DT (c) & O & B \\
\hline Technological design & TP & 4 & $\begin{array}{c}\text { TP DUABD } \\
\text { (c), SO (c) }\end{array}$ & O & B \\
\hline $\begin{array}{l}\text { Logical design of information } \\
\text { and decision systems }\end{array}$ & DL & 5 & $\begin{array}{c}\text { DT, DUABD, } \\
\text { EO }\end{array}$ & O & B \\
\hline Project methodology & MP & 5 & DL, TO & O & B \\
\hline Organization structures & EO & 3 & ECO & O & B \\
\hline Organization techniques & TO & 3 & EO & O & B \\
\hline Organization administration & AO & 4 & EO & O & B \\
\hline Computer centre management & GSI & 2 & DL, TO & O & B \\
\hline Group dynamics & DG & 2 & TO, AO & O & B \\
\hline Law & DE & 2 & AO & O & B \\
\hline
\end{tabular}




\section{Appendix B}

\section{Ingeniero en Informática}

\section{First Cycle}

\begin{tabular}{|l|c|}
\hline \multicolumn{1}{|c|}{ Main Topic and Description } & Credits \\
\hline $\begin{array}{l}\text { Statistics } \\
\text { Descriptive statistics. Probabilities. Applied statistical methods. }\end{array}$ & 6 \\
\hline $\begin{array}{l}\text { Structure Data and Information } \\
\text { Abstract data types. Data structures and manipulation Algorithms. Information } \\
\text { structure: Files, Data bases. }\end{array}$ & 12 \\
\hline $\begin{array}{l}\text { Computer structure and technology } \\
\text { Functional Units: Memory, Processor, Periphery, Machine and Assembly Languages, } \\
\text { Functional schema. Electronics. Digital Systems. Peripheral device. }\end{array}$ & 15 \\
\hline $\begin{array}{l}\text { Informatics physical fundamentals } \\
\text { Electromagnetism. Solid state. Circuits. }\end{array}$ & 6 \\
\hline $\begin{array}{l}\text { Informatics mathematical fundamentals } \\
\text { Algebra. Mathematical Analysis. Discrete Mathematics. Numerical Methods. }\end{array}$ & 18 \\
\hline $\begin{array}{l}\text { Programming Methodology and Technology } \\
\text { Algorithms design. Algorithms analysis. Programming Languages. Programmes } \\
\text { design: Modular decomposition and documentation. Programmes verification and } \\
\text { testing techniques. }\end{array}$ & 15 \\
\hline $\begin{array}{l}\text { Operating Systems } \\
\text { Operating systems organization, structure and services. Memory and processes } \\
\text { management and administration. Input/output management. File systems. }\end{array}$ & \\
\hline $\begin{array}{l}\text { Automata and Formal Languages Theory } \\
\text { Sequential machines and finite automata. Turing machines. Recursive Functions. } \\
\text { Formals grammars and Languages. Neuronal networks. }\end{array}$ & 6 \\
\hline
\end{tabular}

\section{Second Cycle}

\begin{tabular}{|l|c|}
\hline \multicolumn{1}{|c|}{ Main Topic and Description } & Credits \\
\hline $\begin{array}{l}\text { Computer architecture and engineering } \\
\text { Parallel architectures. Architectures oriented to applications and languages. }\end{array}$ & 9 \\
\hline $\begin{array}{l}\text { Software engineering } \\
\text { Requirements analysis and definition. Software design, properties and maintenance. } \\
\text { Configuration management. Planning and management of informatics projects. } \\
\text { Applications analysis. }\end{array}$ & 18 \\
\hline $\begin{array}{l}\text { Artificial Intelligence and knowledge engineering } \\
\text { Heuristics. Knowledge based systems. Learning. Perception. }\end{array}$ & 9 \\
\hline $\begin{array}{l}\text { Language Processors } \\
\text { Compilers, translators and Interpreters. Compiling phases. Code optimization. } \\
\text { Macroprocessors. }\end{array}$ & 9 \\
\hline $\begin{array}{l}\text { Networks } \\
\text { Networks Architecture. Communications. }\end{array}$ & 9 \\
\hline $\begin{array}{l}\text { Informatics Systems } \\
\text { Analysis methodology. Informatics systems configuration, design, management and } \\
\text { evaluation. Informatics systems environments. Advanced technologies of information } \\
\text { systems, data bases and operating systems. Projects of informatics systems. }\end{array}$ & 15 \\
\hline
\end{tabular}




\section{Ingeniero Técnico en Informática de Sistemas}

\begin{tabular}{|l|c|}
\hline \multicolumn{1}{|c|}{ Main Topic and Description } & Credits \\
\hline $\begin{array}{l}\text { Statistics } \\
\text { Descriptive statistics. Probabilities. Applied statistical methods. }\end{array}$ & 6 \\
\hline $\begin{array}{l}\text { Structure Data and Information } \\
\text { Abstract data types. Data structures and manipulation algorithms. Information } \\
\text { structure: Files, data bases. }\end{array}$ & 12 \\
\hline $\begin{array}{l}\text { Computer structure and technology } \\
\text { Functional units: Memory, processor, periphery, machine and assembly languages, } \\
\text { Functional schema. Electronics. Digital systems. Peripheral devices. }\end{array}$ & 15 \\
\hline $\begin{array}{l}\text { Informatics physical fundamentals } \\
\text { Electromagnetism. Solid state. Circuits. }\end{array}$ & 6 \\
\hline $\begin{array}{l}\text { Informatics mathematical fundamentals } \\
\text { Algebra. Mathematical analysis. Discrete mathematics. Numerical methods. }\end{array}$ & 18 \\
\hline $\begin{array}{l}\text { Programming Methodology and Technology } \\
\text { Algorithms design. Algorithms analysis. Programming languages. Programmes design: } \\
\text { Modular decomposition and documentation. Programmes verification and testing } \\
\text { techniques. }\end{array}$ & 12 \\
\hline $\begin{array}{l}\text { Networks } \\
\text { Networks Architecture. Communications. }\end{array}$ & 6 \\
\hline $\begin{array}{l}\text { Operating Systems } \\
\text { Operating systems organization, structure and services. Memory and processes } \\
\text { management and administration. Input/output management. File systems. }\end{array}$ & 6 \\
\hline $\begin{array}{l}\text { Automata and Formal Languages Theory } \\
\text { Sequential machines and finite automata. Turing machines. Recursive Functions. } \\
\text { Formals grammars and Languages. Neuronal networks. }\end{array}$ & 9 \\
\hline
\end{tabular}




\section{Ingeniero Técnico en Informática de Sistemas}

\begin{tabular}{|l|c|}
\hline \multicolumn{1}{|c|}{ Main Topic and Description } & Credits \\
\hline $\begin{array}{l}\text { Statistics } \\
\text { Descriptive statistics. Probabilities. Applied statistical methods. }\end{array}$ & 9 \\
\hline $\begin{array}{l}\text { Structure Data and Information } \\
\text { Abstract data types. Data structures and manipulation algorithms. Information } \\
\text { structure: Files, data bases. }\end{array}$ & 12 \\
\hline $\begin{array}{l}\text { Computer structure and technology } \\
\text { Functional units: Memory, processor, periphery, machine and assembly languages, } \\
\text { Functional schema. Electronics. Digital systems. Peripheral devices. }\end{array}$ & 9 \\
\hline $\begin{array}{l}\text { Business management software engineering } \\
\text { Business management software design, properties and management. Planning and } \\
\text { management of informatics projects. Analysis of management application. }\end{array}$ & 12 \\
\hline $\begin{array}{l}\text { Informatics mathematical fundamentals } \\
\text { Algebra. Mathematical analysis. Discrete mathematics. Numerical methods. }\end{array}$ & 18 \\
\hline $\begin{array}{l}\text { Programming Methodology and Technology } \\
\text { Algorithms design. Algorithms analysis. Programming languages. Programmes design: } \\
\begin{array}{l}\text { Modular decomposition and documentation. Programmes verification and testing } \\
\text { techniques. }\end{array}\end{array}$ & 15 \\
\hline $\begin{array}{l}\text { Operating Systems } \\
\text { Operating systems organization, structure and services. Memory and processes } \\
\text { management and administration. Input/output management. File systems. }\end{array}$ & 6 \\
\hline $\begin{array}{l}\text { Organization techniques and business management } \\
\text { Economic system and business. Administration and accounting techniques. }\end{array}$ & 12 \\
\hline
\end{tabular}




\section{Appendix C}

\section{Ingeniero en Informática}

\section{First Cycle}

\begin{tabular}{|l|c|}
\hline \multicolumn{1}{|c|}{ Main Topic and Description } & Credits \\
\hline $\begin{array}{l}\text { Algebra and discrete mathematics } \\
\text { Basic algebraic structures. Lineal algebra. Combinatory. Discrete structures: graphs, } \\
\text { trees. Logic. Coding. Numerical applications. }\end{array}$ & 12 \\
\hline $\begin{array}{l}\text { Mathematical analysis } \\
\text { Successions and series. Integration. Differential equations. Numerical applications. }\end{array}$ & 6 \\
\hline $\begin{array}{l}\text { Data bases } \\
\text { Data models. Data base management systems. }\end{array}$ & 6 \\
\hline $\begin{array}{l}\text { Statistics } \\
\text { Probabilities. Applied statistical methods. Statistical inference. }\end{array}$ & 6 \\
\hline $\begin{array}{l}\text { Computer structure } \\
\text { Functional units: memory, processor, input/output. Machine and assembly languages. } \\
\text { Running schema. Microprogramming. }\end{array}$ & 12 \\
\hline $\begin{array}{l}\text { Informatics physical fundamentals } \\
\text { Electromagnetism. Electronics. Circuits. }\end{array}$ & 6 \\
\hline $\begin{array}{l}\text { Software engineering fundamentals } \\
\text { Software systems analysis and design. Software properties and maintenance. User } \\
\text { interfaces. }\end{array}$ & 6 \\
\hline $\begin{array}{l}\text { Programming and data structure } \\
\text { Algorithms design and analysis. Programming paradigms and languages. Basic } \\
\text { techniques of programmes design, verification and testing. Object oriented } \\
\text { programming. Abstract data types. Data structures and manipulation algorithms. }\end{array}$ & 21 \\
\hline $\begin{array}{l}\text { Computer networks } \\
\text { Communication elements and systems. Hierarchical structure of networks. Usual types } \\
\text { of networks: local area networks and wide area networks. Network interconnection. } \\
\text { Security. }\end{array}$ & 6 \\
\hline $\begin{array}{l}\text { Operating systems } \\
\text { Operating systems organization, structure and service. Memory, processes and } \\
\text { resources management and administration. Input/output management. File systems }\end{array}$ & 9 \\
\hline $\begin{array}{l}\text { Computer technology } \\
\text { Electronic components and systems of computers. Digital Systems. Microprocessors. } \\
\text { Peripherals structure and functioning. }\end{array}$ & 6 \\
\hline
\end{tabular}




\section{Second Cycle}

\begin{tabular}{|l|c|}
\hline \multicolumn{1}{|c|}{ Main Topic and Description } & Credits \\
\hline $\begin{array}{l}\text { Computer architecture } \\
\text { Speed increasing techniques. Parallel architectures. }\end{array}$ & 9 \\
\hline $\begin{array}{l}\text { Automata theory, formal languages and language processors } \\
\text { Sequential machines and finite automata. Turing machines. Complexity theory. } \\
\text { Recursive functions. Formal grammars and languages. Compilers. Translators and } \\
\text { interpreters. Compilation phases. Macroprocessors. }\end{array}$ & 15 \\
\hline $\begin{array}{l}\text { Software Engineering } \\
\text { Requirements analysis and definition. Software properties and maintenance. Software } \\
\text { quality assurance. Software projects planning and management. Methodologies. } \\
\text { Human-machine interfaces. }\end{array}$ & 15 \\
\hline $\begin{array}{l}\text { Artificial intelligence } \\
\text { Heuristics. Knowledge representation techniques. Knowledge based systems. } \\
\text { Perception. }\end{array}$ & 6 \\
\hline $\begin{array}{l}\text { Networks and distributed systems } \\
\text { Network configuration, administration and management. Interconnection. High } \\
\text { performance networks. Quality of service. Security. Information compressing. } \\
\text { Distributed systems. }\end{array}$ & 9 \\
\hline $\begin{array}{l}\text { Informatics systems } \\
\text { Analysis methodology. Informatics systems configuration, design, management and } \\
\text { evaluation. Informatics systems environments. Advanced technologies of information } \\
\text { systems, data bases and operating systems. Projects of informatics systems. Audit. } \\
\text { Security. }\end{array}$ & 12 \\
\hline
\end{tabular}




\section{Ingeniero Técnico en Informática de Sistemas}

\begin{tabular}{|l|c|}
\hline \multicolumn{1}{|c|}{ Main Topic and Description } & Credits \\
\hline $\begin{array}{l}\text { Algebra and discrete mathematics } \\
\text { Basic algebraic structures. Lineal algebra. Combinatory. Discrete structures: graphs, } \\
\text { trees. Logic. Coding. Numerical applications. }\end{array}$ & 12 \\
\hline $\begin{array}{l}\text { Mathematical analysis } \\
\text { Successions and series. Integration. Differential equations. Numerical applications. }\end{array}$ & 6 \\
\hline $\begin{array}{l}\text { Data bases } \\
\text { Data models. Data base management systems. }\end{array}$ & 6 \\
\hline $\begin{array}{l}\text { Statistics } \\
\text { Probabilities. Applied statistical methods. Statistical inference. }\end{array}$ & 6 \\
\hline $\begin{array}{l}\text { Computer structure } \\
\text { Functional units: memory, processor, input/output. Machine and assembly languages. } \\
\text { Running schema. Microprogramming. }\end{array}$ & 12 \\
\hline $\begin{array}{l}\text { Informatics physical fundamentals } \\
\text { Electromagnetism. Electronics. Circuits. }\end{array}$ & 6 \\
\hline $\begin{array}{l}\text { Software engineering fundamentals } \\
\text { Software systems analysis and design. Software properties and maintenance. User } \\
\text { interfaces. }\end{array}$ & 6 \\
\hline $\begin{array}{l}\text { Programming and data structure } \\
\text { Algorithms design and analysis. Programming paradigms and languages. Basic } \\
\text { techniques of programmes design, verification and testing. Object oriented } \\
\text { programming. Abstract data types. Data structures and manipulation algorithms. }\end{array}$ & 21 \\
\hline $\begin{array}{l}\text { Computer networks } \\
\text { Communication elements and systems. Hierarchical structure of networks. Usual types } \\
\text { of networks: local area networks and wide area networks. Network interconnection. } \\
\text { Security. }\end{array}$ & 6 \\
\hline $\begin{array}{l}\text { Operating systems } \\
\text { Operating systems organization, structure and service. Memory, processes and } \\
\text { resources management and administration. Input/output management. File systems. }\end{array}$ & 6 \\
\hline $\begin{array}{l}\text { Computer technology } \\
\text { Electronic components and systems of computers. Digital Systems. Microprocessors. } \\
\text { Peripherals structure and functioning. }\end{array}$ & 6 \\
\hline $\begin{array}{l}\text { Informatics systems } \\
\text { Management, planning and development of computer systems projects. }\end{array}$ & 6 \\
\hline
\end{tabular}




\section{Ingeniero Técnico en Informática de Gestión}

\begin{tabular}{|l|c|}
\hline \multicolumn{1}{|c|}{ Main Topic and Description } & Credits \\
\hline $\begin{array}{l}\text { Algebra and discrete mathematics } \\
\text { Basic algebraic structures. Lineal algebra. Combinatory. Discrete structures: graphs, } \\
\text { trees. Logic. Coding. Numerical applications. }\end{array}$ & 12 \\
\hline $\begin{array}{l}\text { Mathematical analysis } \\
\text { Successions and series. Integration. Differential equations. Numerical applications. }\end{array}$ & 6 \\
\hline $\begin{array}{l}\text { Data bases } \\
\text { Data models. Data base management systems. }\end{array}$ & 6 \\
\hline $\begin{array}{l}\text { Statistics } \\
\text { Probabilities. Applied statistical methods. Statistical inference.. }\end{array}$ & 6 \\
\hline $\begin{array}{l}\text { Computer structure } \\
\text { Functional units: memory, processor, input/output. Machine and assembly languages. } \\
\text { Running schema. Microprogramming. }\end{array}$ & 12 \\
\hline $\begin{array}{l}\text { Software engineering fundamentals } \\
\text { Software systems analysis and design. Software properties and maintenance. User } \\
\text { interfaces. }\end{array}$ & 6 \\
\hline $\begin{array}{l}\text { Programming and data structure } \\
\text { Algorithms design and analysis. Programming paradigms and languages. Basic } \\
\text { techniques of programmes design, verification and testing. Object oriented } \\
\text { programming. Abstract data types. Data structures and manipulation algorithms. }\end{array}$ & 21 \\
\hline $\begin{array}{l}\text { Computer networks } \\
\text { Communication elements and systems. Hierarchical structure of networks. Usual types } \\
\text { of networks: local area networks and wide area networks. Network interconnection. } \\
\text { Security. }\end{array}$ & 6 \\
\hline $\begin{array}{l}\text { Operating systems } \\
\text { Operating systems organization, structure and service. Memory, processes and } \\
\text { resources management and administration. Input/output management. File systems. }\end{array}$ & 6 \\
\hline $\begin{array}{l}\text { Informatics systems } \\
\text { Management, planning and development of computer business application projects. }\end{array}$ & 6 \\
\hline $\begin{array}{l}\text { Business structure and functions } \\
\text { Business as a system. Management and administration techniques. Organization } \\
\text { structures. }\end{array}$ & 6 \\
\hline $\begin{array}{l}\text { Information systems } \\
\text { Evaluation and management of information systems development. Strategic planning } \\
\text { of information technologies and systems de. Applications. }\end{array}$ & 6 \\
\hline
\end{tabular}

